\title{
PERTUMBUHAN, KELANGSUNGAN HIDUP, DAN PERFORMA PRODUKSI UDANG GALAH, Macrobrachium rosenbergii HASIL SELEKSI PADA TIGA SEGMEN BUDIDAYA
}

\author{
Ikhsan Khasani" dan Asep Sopian \\ Balai Riset Pemuliaan Ikan \\ Jl. Raya 2 Sukamandi, Subang 41263, Jawa Barat
}

(Naskah diterima: 21 Juli 2021; Revisi final: 18 November 2021; Disetujui publikasi:19 November 2021)

\begin{abstract}
ABSTRAK
Pertumbuhan lambat dan maturasi dini merupakan permasalahan serius pada budidaya udang galah karena berdampak pada penurunan produktivitas budidayanya. Seleksi secara simultan pada karakter panjang standar (PS) dan level maturasi (LM) calon induk udang galah betina telah dilakukan dengan tujuan mendapatkan udang galah generasi ketiga (G-3) dengan performa tumbuh cepat dan maturasi lambat. Evaluasi performa benih populasi seleksi (PSL) dan kontrol (PKT), dilakukan pada tiga fase budidaya udang galah, yaitu fase pemeliharaan larva, pendederan, dan pembesaran. Fase pembenihan diperoleh indeks perkembangan larva (IPL) dan kelangsungan hidup $(\mathrm{KH})$ yang lebih baik pada populasi PSL $(9,63 \pm 0,91$ dan $59,43 \pm 9,2 \%$, dibandingkan pada PKT $(8,73 \pm 0,72$ dan 39,64 $\pm 8,4 \%$. Fase pendederan diperoleh PS, bobot badan (BB) dan KH sebesar 19,98 $\pm 2,95 \mathrm{~mm} ; 0,22 \pm 0,10 \mathrm{~g}$; dan 87,27 $\pm 6,70 \%$ untuk PSL, lebih baik dibandingkan pada PKT; (18,70 $\pm 2,72 \mathrm{~mm} ; 0,20 \pm 0,09 \mathrm{~g}$; dan 74,55 $\pm 5,4 \%$. Fase pembesaran, PSL juga menunjukkan keunggulan, dengan PS, BB, dan KH sebesar 68,65 $\pm 8,11 \mathrm{~mm} ; 15,82 \pm 5,67 \mathrm{~g}$; dan $70,5 \pm 1,33 \%$ lebih tinggi dibandingkan PKT; $66,97 \pm 9,72 \mathrm{~mm}$ dan $14,73 \pm 6,86 \mathrm{~g}$; dan $62,8 \pm 18,44 \%$ Level maturitas induk betina pada PSL juga lebih rendah $(1,45 \pm 0,77)$ dibandingkan pada PKT $(1,52 \pm$ 0,94). Data yang diperoleh menunjukkan bahwa seleksi individu secara simultan pada karakter PS dan LM efektif meningkatkan performa pertumbuhan dan produktivitas udang galah.
\end{abstract}

\section{KATA KUNCl: $\quad$ maturitas; panjang standar; pertumbuhan; seleksi; udang galah}

ABSTRACT: Growth, survival, and production performance of the selected giant freshwater prawn, Macrobrachium rosenbergii in three farming stages. By: Ikhsan Khasani and Asep Sopian

Slow growth and early maturation are serious challenges in the giant freshwater prawn (GFP) farming. The simultaneous selection based on standard length $(S L)$ and maturation level $(M L)$ characters of the female giant prawns was carried out to produce the GFP strain ( $3^{\text {th }}$ generation) which had higher productivity. The evaluation of the selection seed (PSL) and the control (PKT) populations was carried out in three phases of the GFP farming, namely the hatchery phase (larval rearing), the nursery, and the grow-out. In the hatchery phase, the larval development index and survival (SR) of the PSL were higher $(9.63 \pm 0.91$ and $59.43 \pm$ $9.2 \%)$ than that of the PKT $(73 \pm 0.72$ and $39.64 \pm 8.4 \%$. In the nursery phase, PS, body weight (BW) and SR of the PSL were $19.98 \pm 2.95 \mathrm{~mm} ; 0.22 \pm 0.10 \mathrm{~g} ; 87.27 \pm 6.70 \%$ They were higher than that of the PKT, there were $18.70 \pm 2.72 \mathrm{~mm} ; 0.22 \pm 0.09 \mathrm{~g}$; and $74.55 \pm 5.4 \%$ In the grow-out phase, the performance of the PSL on PS, BW, and SR were also better, $68.65 \pm 8.11 \mathrm{~mm} ; 15.82 \pm 5.67 \mathrm{~g} ; 70.5 \pm 1.33 \%$ than that of PKT, $66.97 \pm 9.72 \mathrm{~mm}$ and $14.73 \pm 6.86 \mathrm{~g} ; 62.8 \pm 18.44 \%$ The maturity level of female prawns in PSL was also lower $(1.45 \pm 0.77)$ than that of PKT $(1.52 \pm 0.94)$. Based on these data, it can be concluded that simultaneous individual selection on PS and ML characters is effective to improve the growth performance and productivity of the GFP.

KEYWORDS: maturitity; standard length; growth; selection; prawn

\footnotetext{
\# Korespondensi: Balai Riset Pemuliaan Ikan.

Jl. Raya 2 Sukamandi, Subang 41263, Jawa Barat, Indonesia

E-mail: ikhsankhasani@yahoo.com
} 


\section{PENDAHULUAN}

Udang galah, Macrobrachium rosenbergii merupakan anggota famili palaemonid yang memiliki ukuran paling besar di antara udang air tawar lainnya (Wowor \& Ng, 2007), dan saat ini termasuk salah satu spesies udang air tawar yang budidayanya paling berkembang. Budidaya udang galah telah berkembang di sebagian besar negara-negara di Asia Tenggara dan negara-negara di Benua Amerika (Zafar et al., 2015). Pada tahun 2016 total produksi udang galah dunia mencapai 233.898 ton, sedangkan pada tahun 2018 produksi udang galah dunia meningkat menjadi 234.400 ton (FAO, 2020).

Teknologi budidaya udang galah sudah terkuasai dengan baik, dengan biaya produksi relatif rendah karena tidak mengharuskan penggunaan pakan dengan kandungan protein tinggi. Udang galah juga bersifat omnivo rus sehingga dapat dibudidayakan bersama padi (Nair et al., 2013; Dewi et al., 2020). Namun demikian, budidaya udang galah dihadapkan pada permasalahan maturasi dini dan pertumbuhan lambat sehingga menghambat capaian ukuran udang sesuai kebutuhan pasar dan menambah biaya produksi (Khasani et al., 2010; Wijaya et al., 2020). Oleh karena itu, serangkaian kajian dilakukan untuk mengatasi penurunan mutu genetis udang galah, termasuk melalui pendekatan pemuliaan.

Seleksi merupakan salah satu metode pemuliaan untuk merakit strain unggul, dan telah dikembangkan pada sejumlah besar komoditas akuakultur (Gjedrem et al., 2012). Performa unggul pada karakter pertumbuhan (produktivitas) merupakan target utama yang diinginkan, di samping karakter ekonomis penting lainnya, seperti resistensi terhadap penyakit, toleransi terhadap stres, kualitas daging, dan aspek reproduksi (Gjedrem \& Robinson, 2014). Pemuliaan pada karakter pertumbuhan telah dilakukan pada hampir semua komoditas utama di dunia (Gjedrem \& Rye, 2016). Spesifik pada karakter reproduksi, perbaikan genetis telah dilakukan pada ikan trout (Siitonen \& Gall, 1989), nila (Longalong et al., 1999), dan salmon (Iversen et al., 2016).

Dikarenakan udang galah juga mengalami maturasi saat fase pembesaran maka penundaan waktu maturasi pada komoditas udang tawar tersebut merupakan pendekatan strategis untuk dilakukan. Berdasarkan pertimbangan-pertimbangan tersebut maka telah dilakukan program seleksi pada populasi udang galah GI Macro II, yang ditekankan pada karakter pertumbuhan dan level maturitas calon induk udang betina (Anggraeni et al., 2017). Evaluasi performa pertumbuhan dan produktivitas populasi hasil seleksi dilakukan pada tiga fase pemeliharaan, yaitu pemeliharaan larva (pembenihan), pendederan, dan pembesaran dengan tujuan untuk mengetahui peningkatan produktivitas penggunaan benih hasil seleksi.

\section{BAHAN DAN METODE}

Penelitian dilakukan di Balai Riset Pemuliaan Ikan (BRPI), Kementerian Kelautan dan Perikanan, Subang Jawa Barat. Penelitian meliputi tahap pemijahan, pemeliharaan larva, produksi tokolan (pendederan), dan pembesaran udang galah.

Hewan uji yang digunakan berupa populasi induk udang galah GI Macro II generasi kedua (G-2) umur tujuh bulan pasca telur menetas. Induk tersebut merupakan hasil seleksi berdasarkan karakter panjang standar (PS) dan level maturasi (LM) (Anggraeni et al., 2017), dengan metode ringkas sebagai berikut. Seleksi difokuskan pada populasi udang galah betina. Seleksi tahap pertama dilakukan dengan memilih $20 \%$ calon induk betina dengan ukuran PS terbesar, dilanjutkan dengan memilih 50\%calon induk terpilih tersebut yang memiliki LM terendah, selanjutnya disebut sebagai populasi seleksi (PSL). Calon induk udang dengan ukuran PS pada rangking 40\%60\%digunakan sebagai populasi kontrol (PKT). Populasi udang galah betina yang telah diseleksi berdasarkan PS diseleksi lebih lanjut berdasarkan LM. Sementara itu, kriteria calon induk jantan yang digunakan untuk PSL maupun populasi PKT adalah sama, yaitu yang memilliki ukuran besar dengan capit lengkap. Berdasarkan rata-rata panjang standar populasi awal (sebelum dilakukan seleksi) dan rata-rata panjang standar populasi seleksi diperoleh nilai differensial seleksi sebesar $5,29 \mathrm{~mm}$ (nilai relatif sebesar 7,56\%) (Anggraeni et al., 2017).

\section{Pemijahan}

Pemijahan induk udang galah, baik PSL maupun PKT, dilakukan secara komunal di kolam tembok ukuran $200 \mathrm{~m}^{2}$ pada masing-masing populasi dengan perbandingan satu ekor jantan dan dua ekor betina, dengan kepadatan 2 ekor $\mathrm{m}^{-2}$. Jumlah induk yang dipijahkan adalah 100 ekor udang jantan dengan 200 ekor udang betina untuk populasi terseleksi; 165 ekor induk jantan dan 330 ekor induk betina untuk populasi kontrol.

Pemijahan dilakukan selama 20 hari, dengan pemberian pakan khusus udang (kandungan protein kasar $32 \%$ sebanyak $2 \%$ biomassa dengan tiga kali waktu pemberian. Induk-Induk betina yang telah memijah dan mengerami telur berwarna kecokelatan (2-3 hari telur akan menetas) dipindahkan ke corong penetasan yang telah disterilkan dengan formalin dengan dosis $250 \mathrm{mg} / \mathrm{L}$ selama 60 detik dan diisi air steril dengan salinitas $5 \%$ hingga telur menetas menjadi larva. 


\section{Pemeliharaan Larva}

Pemeliharaan larva dilakukan dengan sistem air jernih dan secara rutin dilakukan peergantian air sebanyak 20\%per hari setelah pemberian pakan buatan. Larva yang baru menetas didesinfeksi dengan memasukkan ke dalam larutan formaldehide $200 \mathrm{mg} / \mathrm{L}$ selama 30 detik. Larva dipelihara dengan kepadatan 50 ekor $\mathrm{L}^{-1}$ dalam wadah corong pemeliharaan volume 60 liter pada media air payau bersalinitas $12 \%$ Naupli Artemia sp. diberikan pada larva umur tiga hari hingga panen, diberikan dalam dua kali waktu pemberian. Pakan buatan (egg custard) dengan bahan berupa cumi $(20 \%)$, susu bubuk $(4 \%$, telur $(34 \%$, tepung terigu $(2 \%)$, minyak ikan $(0,8 \%$, vitamin mix $(0,7 \%)$, mineral mix $(0,7 \%$ diberikan setelah pemeliharaan memasuki hari ke-11 hingga panen dan diberikan dalam tiga kali waktu pemberian. Formula pakan buatan dan jumlah pakan yang diberikan mengacu pada Dhont et al. (2010). Pengamatan perkembangan larva udang galah dilakukan dengan menghitung indeks perkembangan stadia larva (larval stage index/LSI). Pengamatan stadia larva dilakukan setiap tiga hari sekali, dengan mengamati 20 ekor larva di bawah mikroskop dengan perbesaran 40x, untuk setiap wadah pemeliharaan. Penentuan stadia larva berdasarkan morfologi larva, dengan mengacu pada kunci identifikasi stadia larva udang galah (Brown et al., 2010). Panen total dilakukan pada hari ke-35 setelah semua larva mencapai stadia pascalarva ( $\mathrm{PL})$. Data kelangsungan hidup $(\mathrm{KH})$ didasarkan pada perbandingan jumlah PL yang diperoleh dibagi jumlah larva yang ditebar. Perhitungan perkembangan stadia larva mengacu pada Mallasen \& Vallenti (2005) dan Nhan (2009).

\section{Pendederan}

Pemeliharaan PL dilakukan di kolam tembok ukuran $25 \mathrm{~m}^{2}$ dengan padat tebar 400 ekor $\mathrm{m}^{-2}$, selama 30 hari. Masing-masing populasi, seleksi, dan kontrol, dipelihara pada tiga buah kolam sebagai ulangan. Pakan udang galah bentuk butiran (diameter 0,5-1 mm) dengan kandungan protein kasar 38\%40\% diberikan sebanyak $20 \%$ biomassa dengan tiga kali waktu pemberian. Kualitas air dipertahankan dengan memasukkan air baru sebanyak 10\%20\%volume per hari. Panjang total (PT), panjang standar (PS), bobot badan (BB), dan kelangsungan hidup (KH) benih udang diamati pada akhir pemeliharaan. Perhitungan juga dilakukan untuk koefisien variasi PT, PS, dan BB.

\section{Pembesaran}

Proses pembesaran dilakukan selama empat bulan. Benih berupa tokolan 1 (panjang total $2-4 \mathrm{~cm}$ ) dipeliharan di kolam tanah ukuran $200 \mathrm{~m}^{2}$ dengan kepadatan 10 ekor $\mathrm{m}^{-2}$. Masing-masing populasi, seleksi, dan kontrol, dipelihara pada tiga buah kolam sebagai ulangan. Pakan komersial dengan kandungan protein kasar 30\%32\%diberikan sebanyak 15\%(bulan pertama); $10 \%$ (bulan kedua); dan 7,5\%(bulan ketiga); dan $5 \%$ (bulan keempat) dari bo bot biomassa per hari, berdasarkan bobot rata-rata udang dan prediksi penurunan kelangsungan hidup. Pakan diberikan dalam tiga kali waktu pemberian per hari. Parameter yang diamati meliputi PT, PS, BB, kelangsungan hidup, biomassa saat panen, level maturasi induk betina dan persentase induk bertelur. Level maturasi induk betina dikelompokkan menjadi lima tipe dengan mengacu pada Sagi \& Ra'anan (1985); Revathi et al. (2012).

\section{Analisis Data}

Data LSI, PT, PS, BB, KH, biomassa, persentase induk bertelur, dan level maturitas ditampilkan dalam nilai rata-rata dengan standar deviasi atas ulangan. Analisis statistik dilakukan menggunakan SPSS 16.0. Perbedaan performa antara kedua populasi ditentukan dengan menggunakan uji t.

\section{HASIL DAN BAHASAN}

Seleksi terhadap populasi dasar udang galah GI Macro II pada karakter panjang standar (PS) dan level maturitas (LM) diperoleh populasi induk seleksi dan kontrol dengan perbedaan ukuran yang cukup besar, yaitu sebesar 19,81 mm pada karakter panjang standar dan 14,21 g pada karakter bobot badan (Tabel 1).

Seleksi, pada populasi udang galah GI Macro II diperoleh nilai differensial seleksi sebesar $5,29 \mathrm{~mm}$ (7,56\%) berdasarkan karakter panjang standar (Anggraeni et al., 2017). Dengan keunggulan performa tumbuh calon induk terseleksi dibandingkan tetuanya tersebut akan diperoleh perbaikan genetik per generasi sebesar 4,7\%10,7\% pada karakter panjang dan 12\% $30 \%$ pada karakter bobot badan (Khasani et al., 2018). Prinsip yang mendasari dilakukannya seleksi adalah nilai genetik rata-rata individu terseleksi lebih tinggi daripada nilai genetik rata-rata dari seluruh individu dalam populasi, sehingga menghasilkan keturunan dengan nilai genetik yang lebih baik daripada individuindividu dalam populasi tetuanya (Hung, 2013). Keunggulan tersebut diharapkan akan terekspresi pada semua fase kehidupan udang galah sehingga berdampak positif terhadap peningkatan produktivitas dan keuntungan usaha.

\section{Perkembangan Larva}

Pada hari ke-18 periode pemeliharaan larva (pembenihan), perkembangan larva udang galah populasi seleksi lebih cepat (nilai LSI sebesar 9,63 \pm 0,69 ) dibandingkan populasi kontrol (nilai LSI sebesar $8,73 \pm 0,56)$, meskipun secara statistik tidak berbeda 
Tabel 1. Rerata panjang standar dan bobot induk udang galah seleksi dan kontrol

Table 1. The average of standard length and body weight of the selected and control giant freshwater prawns

\begin{tabular}{lcc}
\hline Populasi (Population) & Panjang standar (Standard length $(\mathbf{m m})$ & Bobot badan (Body weight ) (g) \\
\hline Seleksi (Selected) & $103.54 \pm 12.47$ & $42.86 \pm 9.74$ \\
Kontrol (Control) & $83.63 \pm 14.16$ & $18.65 \pm 4.97$ \\
\hline
\end{tabular}

nyata $(P>0,05)$. Selain itu, sintasan larva populasi seleksi selama 30 hari pemeliharaan juga lebih tinggi $(\mathrm{P}<0,05)$, yaitu sebesar $59,43 \pm 8,23 \%$ dibandingkan populasi kontrol, sebesar 39,64 \pm 7,31\%(Gambar 1).

Performa unggul populasi seleksi ternyata telah muncul pada fase larva yang merupakan fase paling kritis, dikarenakan pertumbuhan larva udang galah selalu disertai dengan proses pergantian karapas (molting) yang menyebabkan larva lemah dan memicu kanibalisme (Brown et al., 2010). Perkembangan larva hingga bermetamorfosis menjadi pascalarva dilalui dengan 11 kali ganti kulit (molting) dengan perubahan morfologi yang khas (Mohapatra \& Guru, 2015). Berdasarkan kurva perkembangan larva (Gambar 1A), mulai hari ke-9 larva PSL terlihat berkembang lebih baik, meskipun secara statistik tidak menunjukkan perbedaan nyata. Namun demikian, dengan tingkat sintasan yang juga lebih tinggi, sehingga kompetisi ruang dan oksigen lebih tinggi, maka sangat nyata bahwa potensi tumbuh larva PSL lebih baik. Dinyatakan oleh Paul et al. (2016) bahwa perbedaan padat tebar akan berpengaruh terhadap tingkat kompetisi antar larva dalam memperoleh makanan dan ruang. Dinyatakan oleh Mohapatra et al. (2015) bahwa perkembangan larva udang galah sangat dipengaruhi oleh faktor lingkungan dan jumlah pakan yang diberikan.

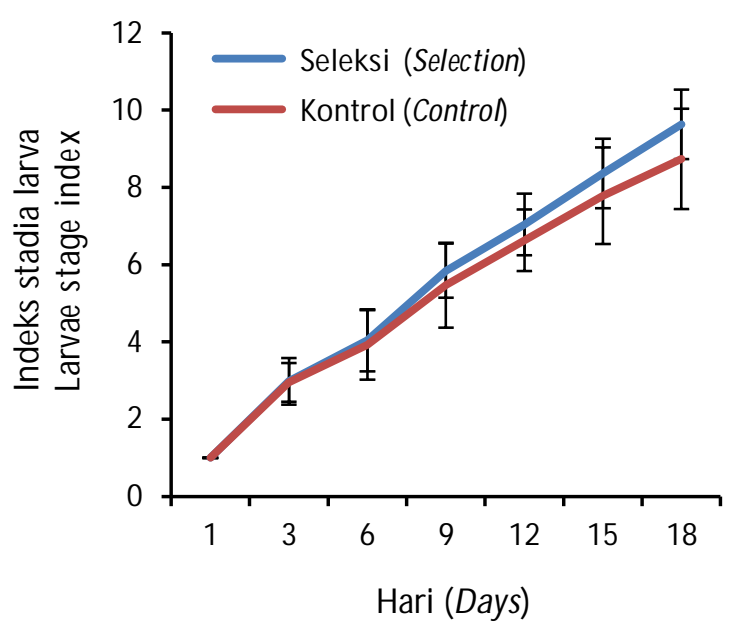

Pada segmen pembenihan, khususnya produksi benur, jumlah benih yang dihasilkan pada akhir siklus (ditunjukkan dengan nilai sintasan) merupakan aspek yang lebih penting dibandingkan ukuran benih. Sintasan larva pada penelitian ini $(59,43 \%)$ tergolong tinggi dibandingkan penelitian sebelumnya. Zafar et al. (2015) menyatakan bahwa sintasan larva udang galah yang dipelihara pada beberapa level salinitas sebesar 12,0\% $50,83 \%$ Demikian pula yang dilaporkan oleh Bashar et al. (2012) bahwa sintasan larva udang galah yang dipelihara dengan kepadatan 100-300 ekor/L sebesar $21,8 \% 51,3 \%$

Perbedaan sintasan larva pada PSL dan PKT hingga 20\% (nilai mutlak) atau 50\%(nilai relatif) merupakan capaian yang sangat tinggi dan akan berdampak pada peningkatan keuntungan yang diperoleh. Hasil penelitian menunjukkan bahwa tingkat sintasan larva pada populasi induk terseleksi sampai akhir pemeliharaan signifikan lebih tinggi dibandingkan dengan populasi induk kontrol $(\mathrm{P}<0,05)$ (Gambar 1$)$. $\mathrm{Hal}$ tersebut mengindikasikan bahwa populasi terseleksi memiliki tingkat toleransi lebih baik terhadap kondisi lingkungan pemeliharaan. Krettiawan et al. (2013) menyatakan bahwa tingkat toleransi udang galah seleksi terhadap perubahan beberapa parameter fisika-kimia air lebih tinggi dibandingkan populasi pembandingnya (kontrol).

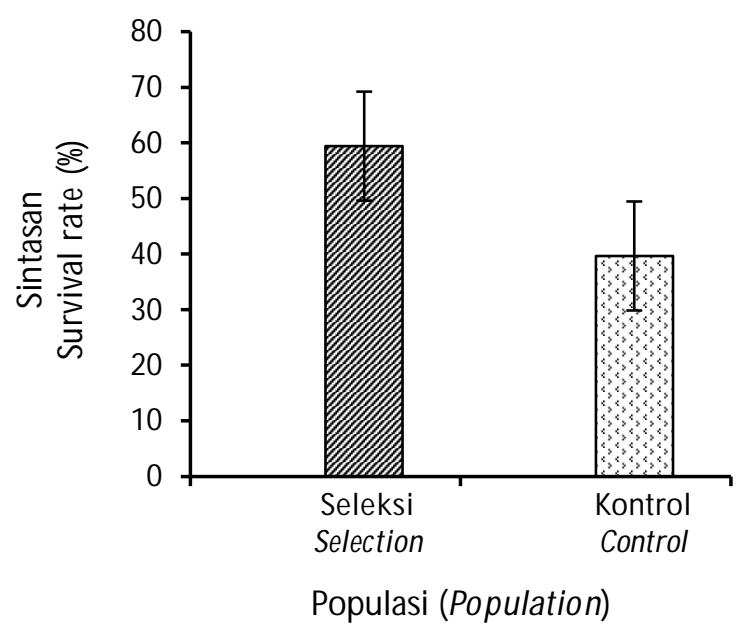

Gambar 1. Indeks stadia larva (A) dan sintasan (B) larva udang galah seleksi dan kontrol.

Figure 1. Larval stage index (A) and survival rate (B) of the selected and control of giant freshwater prawn larvae. 


\section{Pendederan}

Keunggulan populasi PSL atas PKT teramati pula padafase pendederan, baik pada karakter pertumbuhan dan sintasan. Perbedaan tersebut lebih terlihat nyata karakter sintasan (Tabel 2).

Pada fase pendederan, pertumbuhan bobot, dan sintasan benih udang galah seleksi pada fase pendederan lebih baik dibandingkan populasi kontrol. Performa lebih unggul tersebut sangat dimungkinkan disebabkan oleh faktor tingkat toleransi benih seleksi terhadap fluktuasi suhu kolam lebih baik dibandingkan benih kontrol. Pemeliharaan pascalarva dilakukan secara outdoor sehingga suhu air berfluktuasi cukup tinggi dengan kisaran $25^{\circ} \mathrm{C}-34^{\circ} \mathrm{C}$. Performa unggul benih hasil seleksi pada fase pendederan selaras dengan yang dilaporkan oleh Khasani et al. (2017) yang menyatakan bahwa benih udang galah hasil seleksi memiliki tingkat toleransi lebih tinggi terhadap fluktuasi suhu kolam sehingga sintasan benih juga lebih tinggi. Pada segmen pembenihan, sintasan benih (jumlah benih yang dihasilkan saat panen) merupakan paramater utama, di samping ukuran (kualitas) benih tersebut. Perbedaan sintasan antara benih seleksi dengan benih kontrol pada fase pendederan sebesar $13 \%$ (nilai relatif sebesar $17 \%$ merupakan peningkatan yang sangat berarti dalam usaha produksi benih (tokolan) udang galah, dan akan berimplikasi terhadap tingkat keuntungan usaha tersebut.

Sintasan benih selama pendederan pada penelitian ini sebesar $87,27 \pm 6,7 \%$ (PSL) dan 74,55 $\pm 5,40 \%$ (PKT), tergolong tinggi dibandingkan yang dilaporkan oleh Avillanosa et al. (2019) yang menyatakan bahwa sintasan benih udang galah yang dipelihara dengan beberapa jenis shelter sebesar 40,0\%55,6\% Demikian pula yang dilaporkan oleh Mamun et al. (2010) yang menyatakan bahwa sintasan benih udang galah pada sistem pendederan dengan jenis shelter berbeda sebesar $80 \% 83 \%$

\section{Pembesaran}

Performa tumbuh lebih cepat dengan sintasan lebih tinggi teramati pula pada fase pembesaran selama empat bulan. Meskipun secara statistik tidak menunjukkkan perbedaan nyata, akan tetapi perbedaan capaian biomassa sebesar 20,5\% (peningkatan relatif biomassa PSL dan PKT) merupakan nilai yang sangat bermakna pada suatu sistem produksi. Performa pertumbuhan dan sintasan udang galah selama fase pembesaran dituangkan pada Tabel 3.

Pada segmen pembesaran dengan padat tebar awal 10 ekor $/ \mathrm{m}^{2}$, sintasan udang galah termasuk kategori sedang yaitu 70,5 $\pm 13,3 \%$ (PSL) dan $62,8 \pm 18,44 \%$ (PKT). Demikian pula pada parameter biomassa udang galah saat panen, yaitu $1.116 \pm 132 \mathrm{~kg} \mathrm{ha}^{-1}$ (PSL) dan $924 \pm 336 \mathrm{~kg} \mathrm{ha}^{-1}$ (PKT). Correia et al. (2003) menyatakan bahwa pada kegiatan budidaya udang galah semi-intensif dengan padat tebar 6 ekor $\mathrm{m}^{-2}$ diperoleh sintasan sebesar $84 \% 86 \%$ dengan biomassa sebesar $1.246 \mathrm{~kg} \mathrm{ha}^{-1}$.

Performa unggul populasi seleksi dibandingkan populasi kontrol lebih terlihat pada karakter sintasan dan biomassa udang saat panen. Keunggulan relatif populasi seleksi atas populasi kontrol sebesar $12,26 \%$ pada karakter sintasan dan 20,78\% pada karakter

Tabel 2. Pertumbuhan dan sintasan populasi seleksi dan populasi kontrol pada fase pendederan udang galah

Table 2. Growth and survival rate of the selected and control population in the nursery phase of the giant freshwater prawn

\begin{tabular}{|c|c|c|}
\hline $\begin{array}{l}\text { Karakter } \\
\text { Characters }\end{array}$ & $\begin{array}{l}\text { Populasi terseleksi } \\
\text { Selected }\end{array}$ & $\begin{array}{l}\text { Populasi kontrol } \\
\text { Control }\end{array}$ \\
\hline Panjang standar (Standard length ) (mm) & $19.98 \pm 2.95^{\mathrm{a}}$ & $18.70 \pm 2.72^{\mathrm{a}}$ \\
\hline $\begin{array}{l}\text { Ko efisien variasi panjang standar } \\
\text { Variation co efficient of standard length }(\%)\end{array}$ & 14,74 & 14,55 \\
\hline Panjang total (Total length ) (mm) & $31.54 \pm 7.62^{\mathrm{a}}$ & $30.04 \pm 6.15^{a}$ \\
\hline $\begin{array}{l}\text { Ko efisien variasi panjang total } \\
\text { Variation co efficient of total length }(\%)\end{array}$ & 24,15 & 20,47 \\
\hline Bobot badan (Body weight) $(\mathrm{g})$ & $0.26 \pm 0.10^{\mathrm{a}}$ & $0.22 \pm 0.09^{\mathrm{a}}$ \\
\hline $\begin{array}{l}\text { Ko efisien variasi bobot } \\
\text { Variation co efficient of body weight (\%) }\end{array}$ & 38,15 & 41,33 \\
\hline Sintasan (Survival rate) $(\%$ & $87.27 \pm 6.70^{\mathrm{a}}$ & $74.55 \pm 5.40^{b}$ \\
\hline
\end{tabular}


Tabel 3. Pertumbuhan dan sintasan populasi seleksi dan populasi kontrol pada akhir fase pembesaran

Table 3. Growth and survival rate of the selected and control populations in the grow-out phase

\begin{tabular}{|c|c|c|}
\hline $\begin{array}{l}\text { Karakter } \\
\text { Characters }\end{array}$ & $\begin{array}{l}\text { Populasi tersel eksi } \\
\text { Selected }\end{array}$ & $\begin{array}{l}\text { Populasi kontrol } \\
\text { Control }\end{array}$ \\
\hline Panjang standar (Standard length ) (cm) & $68.65 \pm 8.11^{\mathrm{a}}$ & $66.97 \pm 9.72^{\mathrm{a}}$ \\
\hline Panjang total (Total length) $(\mathrm{cm})$ & $111.58 \pm 13.56^{\mathrm{a}}$ & $107.63 \pm 17.45^{\mathrm{a}}$ \\
\hline Bobot badan (Body weight) (g) & $15.82 \pm 5.67^{\mathrm{a}}$ & $14.73 \pm 6.86^{\mathrm{a}}$ \\
\hline Biomassa (Biomass) (kg ha-1) & $1.116 \pm 132^{\mathrm{a}}$ & $924 \pm 336^{a}$ \\
\hline Sintasan (Survival rate) $(\%)$ & $70.5 \pm 13.3^{\mathrm{a}}$ & $62.8 \pm 18.44^{\mathrm{a}}$ \\
\hline $\begin{array}{l}\text { Kelas maturitas udang betina } \\
\text { Maturation level of female prawn }\end{array}$ & $1.45 \pm 0.77^{\mathrm{a}}$ & $1.52 \pm 0.94^{\mathrm{a}}$ \\
\hline $\begin{array}{l}\text { Persentase induk bertelur } \\
\text { The percentage of gravide female ( } \% \text { ) }\end{array}$ & $0.0 \pm 0.0^{a}$ & $15.7 \pm 2.51^{b}$ \\
\hline
\end{tabular}

biomassa udang saat panen. Peningkatan sebesar 20,78\%tersebut akan memberikan keuntungan sangat berarti dalam sistem budidaya udang galah. Selain meningkatkan produksi udang, seleksi yang dilakukan juga menekan laju maturitas calon induk udang galah betina. Meskipun secara statistik level maturitas udang galah PSL $(1,45 \pm 0,77)$ tidak menunjukkan perbedaan nyata dengan udang PKT $(1,52 \pm 0,94)$, akan tetapi persentase induk yang bertelur dan pasca bertelur (abdomen melebar) pada PSL $(0,0 \pm 0,0 \%$ berbeda sangat nyata dibandingkan pada PKT $(15,7 \pm 2,51 \%)$. Perbedaan jumlah induk bertelur sebesar $15,7 \%$ merupakan capaian yang cukup besar dan selaras dengan yang dilaporkan pada penelitian-penelitian sebelumnya. Gjerde \& Korsvoll (1999) melaporkan bahwa seleksi berdasarkan karakter maturitas pada ikan salmon diperoleh penurunan jumlah ikan yang matang seksual sebesar $12,5 \%$ Keberhasilan lebih tinggi dilaporkan oleh Longalong et al. (1999) yang menyatakan bahwa seleksi secara simultan pada karakter pertumbuhan dan level maturitas pada ikan nila GIFT diperoleh penurunan jumlah ikan yang matang seksual sebesar $24,5 \%$

Perlambatan maturitas induk pada udang galah sangat penting dilakukan karena maturitas dini tersebut berdampak pada penghambatan Iaju pertumbuhan. Dinyatakan oleh Franco et al. (2006) bahwa ketika udang mengalami maturasi, maka sebagian energi dari pakan akan digunakan untuk proses reproduksi sehingga alokasi energi untuk pertumbuhan somatik terganggu dan berdampak pada pertumbuhan, ukuran udang ketika panen tidak mencapai ukuran yang dibutuhkan pasar.

\section{KESIMPULAN}

Seleksi secara simultan pada karakter panjang standar dan level maturasi menghasilkan populasi udang galah yang memiliki performa tumbuh dan sintasan lebih tinggi dibandingkan populasi kontrol. Seleksi tersebut juga efektif menurunkan level maturitas induk betina pada periode pembesaran sehingga berpotensi meningkatkan capaian ukuran saat panen.

\section{UCAPAN TERIMA KASIH}

Apresiasi dan penghargaan yang setinggi-tingginya pada Kepala Balai Riset Pemuliaan Ikan (Dr. Joni Hariyadi, M.Sc.), teknisi udang (A. Ali Akbar, Dede Sukarta, Karta, dan Galih Prayitno) atas dukungan pendanaan, pemikiran, dan teknis selama persiapan dan pelaksanaan penelitian.

\section{DAFTAR ACUAN}

Anggraeni, F., Krettiawan, H., \& Astuti, D.N. (2017). Peningkatan mutu genetis udang galah melalui seleksi individu pada karakter pertumbuhan dan kematangan udang galah betina. Laporan Hasil Penelitian. Badan Riset Sumberdaya Manusia Kelautan dan Perikanan. Pusat Riset Perikanan. Balai Riset Pemuliaan Ikan.

Avillanosa, A.L., Ecube, K.M.A., Española, M.D., Caipang, C.M.A., Palla, H.P., \& Becir, J.G. (2019). Effects of stocking density and artificial shelters during the nursery production of giant freshwater prawn, Macrobrachium rosenbergii (De Man, 1879 ) in net cages. International Journal of Aquatic Science, 10(2), 76-82. 
Bashar, M .A., Khan, M.H., Rashid, M.H., Rahman, M.M., \& Ahmed, K.K.U. (2012). Growth, survival and diseases stress of Macrobrachium rosenbergii larvae at different stocking densities in cemented tank under hatchery condition. Journal of Agroforest and Environment, 6(1), 143-147.

Brown, J.H., New, M.B., \& Ismael, D. (2010). Biology. In: New, M.B., Valenti, W.C., Tidwell, J.H., D'Abramo, L.R., Kutty, M.N. (Eds.). Freshwater Prawns Biology and Farming, p. 17-39. Lowa (USA): Blackwell Publishing Ltd.

Correia, E.S., Pereira, A.P., \& Silva, A. (2003). Growout of freshwater prawn Macrobrachium rosenbergii in fertilized ponds with reduced levels of formulated feed. Journal of The World Aquaculture Society, 34(2), 184-191.

Dewi, R.R.S.P., Krettiawan, H., Anggraeni, F., Kusnendar, E., \& Kusdiarti. (2020). Productivity and profitability of rice-freshwater prawn culture in different stocking density of prawn. IOP Conf. Series: Earth and Environmental Science, 521, 1-8. DOI: 10.1088/1755-1315/521/1/012021.

Dhont, J., Wille, M., Frinsko, M., Coyle, S.D., \& Sorgeloos, P. (2010). Larval feeds and feeding. In: New, M.B., Valenti, W.C., Tidwell, J.H., D'Abramo, L.R., Kutty, M.N. (Eds.). Freshwater Prawns Biology and Farming, p. 86-106. Lowa (USA): Blackwell Publishing Ltd.

FAO. (2020). The State of World Fisheries and Aquaculture 2020. Sustainability in action. Rome. https:/ /doi.org/10.4060/ca9229en. 224 pp.

Franco, A.R., Ferreira, J.G., \& Nobre, A.M. (2006). Development of a growth model for penaeid shrimp. Aquaculture, 259(1-4), 268-277. doi: 10.1016/j.aquaculture.2006.05.051.

Gjedrem, T., Robinson, N., \& Rye, M. (2012). The importance of selective breeding in aquaculture to meet future demands for animal protein: A review. Aquaculture, 350353, 117-129.

Gjedrem, T. \& Robinson, N. (2014). Advances by selective breeding for aquatic species: a review. Agricultural Sciences, 5, 1152-1158.

Gjedrem, T., \& Rye, M. (2016). Selection response in ûsh and shellûsh: a review. Reviews in Aquaculture: 1-12. Doi:10.1111/raq.12154.

Gjerde, B. \& Korsvoll, S.A. (1999). Realized selection differentials for growth rate and early sexual maturity in Atlantic salmon. p 73-74. In Abstracts, Aquaculture Europe 99. European Aquaculture Society, Special Publication No. 27, Trondheim, Norway.
Hung, D. (2013). Genetic improvement of freshwater giant prawn in Vietnam. Thesis. Queensland University of Technology, Brisbane, Australia.

Iversen, M., Myhr, A.I., \& Wargelius, A. (2016): Approaches for delaying sexual maturation in salmon and their possible ecological and ethical implications. Journal of Applied Aquaculture, p. 1-15. DOI: 10.1080/10454438.2016.1212756.

Khasani, I., Imron, Suprapto, R., \& Himawan, Y. (2010). Evaluasi performa pertumbuhan persilangan udang galah (Macrobrachium rosenbergii) dari beberapa populasi. Seminar Nasional Akuakultur dan Perikanan, hlm. 581-590. Yogyakarta, 24-25 Juli 2010.

Khasani, I., Alimuddin, Lusiastuti, A.M., \& Zairin, M.Jr. (2017). Resistance to vibriosis, production performance and tolerance to stress of the selected giant freshwater prawn (Macrobrachium rosenbergii). Aquaculture Research, p. 1-9.

Khasani, I., Krettiawan, H., Sopian, A., \& Anggraeni, F. (2018). Selection response and heritability of growth traits of giant freshwater prawn (Macrobrachium rosenbergii) in Indonesia. AACL Bioflux, 11(6), 1688-1695.

Krettiawan, H., Imron, Khasani, I., Sopian, A., Anggraeni, F., \& Suprapto, R. (2013). Naskah Akademis Udang Galah GI Macro II, Macrobrachium rosenbergii. Balai Penelitian Pemuliaan Ikan. Pusat Penelitian dan Pengembangan Perikanan Budidaya. Badan Penelitian dan Pengembangan Kelautan dan Perikanan, $66 \mathrm{hlm}$.

Longalong, F.M., Eknath, A.E., \& Bentsen, H.B. (1999). Response to bi-directional selection for frequency of early maturing females in nile tilapia (Oreochromis niloticus). Applied Aquaculture, 178, 13-25.

Mallasen, M. \& Vallenti, W.C. (2005). Larval development of the giant river prawn Macrobrachiurn rosenbergii at different ammonia concentrations and $\mathrm{pH}$ values. Journal of The World Aquaculture Society, 36(1), 32-41.

Mamun, M.A.A., Hossain, M.A., \& Hossain, M.S. (2010). Effects of different types of artificial substrates on nursery production of freshwater prawn, Macrobrachium rosenbergii (de $M$ an) in recirculatory system. Journal of Bangladesh Agriculture University, 8(2), 333-340.

Mohapatra, P.K. \& Guru, B.V. (2015). Application of modern technology in freshwater prawn seed production: A case study at Chandrabhaga Prawn Hatchery, Konark, Odisha. International Journal of Bioassay, 4(9), 4305-4308. 
Nair, C.M., Salin, K.R., Joseph, J., Aneesh, B., Geethalakshmi, V., \& New, M.B. (2013). Organic rice-prawn farming yields $20 \%$ higher revenues. Agronomy Sustainable Development, p. 1-15. DOI: 10.1007/s13593-013-0188-z.

New, M.B. \& Valenti, W.C. (2000). Freshwater prawn culture: the farming of Macrobrachium rosenbergii. Blackweill Science, 443 pp.

Nhan, D.T. (2009). Optimization of hatchery protocols for Macrobrachium rosenbergii culture in Vietnam. PhD Thesis. Ghent University, Belgium.

Paul, P., Rahman, M.A., Hosain, M.M., Islam, M.D., Mondal, S., \& Haq, M.M. (2016). Effect of stocking density on the growth and production of freshwater prawn (M acrobrachium rosenbergii). International Journal of Fisheries and Aquaculture Sciences, $6(1), 77-86$.

Revathi, P., Iyapparaj, P., M unuswamy, N., \& Krishnan, M. (2012). Vitellogenesis during the ovarian development in freshwater female prawn Macrobrachium rosenbergii (De Man). International Journal of Aquatic Science, 3(2), 13-27.

Sagi, A. \& Ra'anan, Z. (1985). Rapid identification of reproductive state and the receptive period of females in pond populations of Macrobrachium rosenbergii a new technique. Aquaculture, 48, $36 \mathrm{I-}$ 361.

Siitonen, L. \& Gall, G.A.E. (1989). Response to selection for early spawn date in rainbow trout, Salmo gaidneri. Applied Aquaculture, 78, 153-161.

Wijaya, M., Sudrajat, M.0., \& Imron. (2020). Reproductive and growth performances in female giant freshwater prawn following inhibition of gonadal maturation using dopamine and medroxyprogesterone hormone. Jurnal Akuakultur Indonesia, 19(1), 10-18.

Wowor, D. \& Ng, P.K.L. (2007). The giant freshwater prawns of the Macrobrachium rosenbergii species group (crustacea: decapoda: caridea: palaemonidae). The Raffles Bulletin of Zoology, 55(2), 321-336.

Zafar, M., Soomro, M.H., Daudpota, A.M., Memon, A.J., \& Ishaqi, AM. (2015). Effect of different salinities on survival of freswater prawn (Macrobrachium rosenbergii) larvae at seed production unit Hawksbay Karachi-Pakistan. International Journal of Interdisciplinary and M ultidisciplinary, 2(5), 165-169. 